\title{
It's all about the relationships Interlibrary lending for a nonresidency PhD program
}

A recent editorial on the future of libraries ended with a quote by computer science icon Alan Kay, "The best way to predict the future is to invent it." When I was first approached by George Smith, president of the Institute for Doctoral Studies in the Visual Arts (IDSVA), ${ }^{2}$ to act as a library consultant for their new PhD program in 2006, I think I embraced the sentiment of Kay's statement wholeheartedly. I'd spent the majority of my library career working with art departments and art schools, often developing new services tailored to the specific needs of the students and faculty. But in every instance, the programs, services, and collections were strongly tied to a physical library.

The challenge, and part of the allure, of working with IDSVA, was that IDSVA was not only designing the first PhD in Art Theory for studio artists, but that it was not associated with an established campus or library. Instead, students would attend brief residencies each year, currently offered in Italy, France, Germany, New York, Istanbul, and Providence. They would work intensely with guest faculty at the residencies, and then continue with a small group of core faculty during the rest of year.

The concept of the PhD for artists is controversial in and of itself. G. James Daichendt writes in his introduction to Artist Scholar that writing and reflecting are essential components he looked for in Master of Fine Arts programs. But he found a failing in many current $\mathrm{PhD}$ programs for art, where the focus is on research, to the extent that the art gets lost. ${ }^{3}$ This is where IDSVA differs, in that it is not using art as extension of social science research, but instead is focusing on art theory. While not for every artist, for those who want to explore it, art theory can open new avenues of exploration in their own artwork, as well as new understanding of their art never before reached.

Many schools now offer non- or low-residency degree programs, and there are many approaches to working with nonresident students. E-mail, teleconferencing, video conferencing, blogs, and file sharing, combined with the residencies, make it possible for the small cohorts at IDSVA to work together with their faculty and bind into strong cohorts that can provide each other with the dialogue and feedback so essential to a $\mathrm{PhD}$ program.

At the same time, it was interesting to consider whether a born digital library could work for PhD students as well as the curriculum does. As a fledgling institution, funds were limited and IDSVA did not have a traditional brick and mortar library to support the program. This idea was so intriguing that the challenge to try and develop a digital library for $\mathrm{PhD}$ students in art theory was irresistible.

Happily, the timing of developing IDSVA's library coincided with the growth of many

Laura Graveline is library director for the Institute for Doctoral Studies in the Visual Arts and visual arts librarian at Dartmouth College, e-mail: Igraveline@ idsva.org

() 2014 Laura Graveline 
free online resources that already support traditional library resources, including:

- worldcat.org

- artlibraries.net

- Project Gutenberg

- Google Books

- Google Scholar

- Stanford Encyclopedia of Philosophy

However, we still needed to invest in reputable, peer-reviewed resources, which would provide full text upfront to our students, such as:

- JSTOR

- Project Muse

- ARTSTOR

- Oxford English Dictionary

- Chicago Manual of Style

The one problem I could not see a way to surmount was interlibrary access to physical materials. Document delivery of PDFs of articles or essays was manageable, but we had no recourse for our students to request physical items. Without a physical library to deliver the items to, we could not provide this service to our students.

Many of IDSVA's PhD students are already associated with a research library near their homes, but this could not be guaranteed for every student. In 2010, I looked at institutions of different sizes, most with large, well-established nonresidency programs, in the hopes of gathering some ideas about how other schools handed this kind of dilemma.

\section{Interlibrary loan service and document delivery}

In order to assess how other programs have dealt with this issue, IDSVA looked at five library distance service programs: Maine College of Art, Harvard School of Business, Indiana University School of Education, Dartmouth College, and Champlain College. All the libraries responded, except for Champlain College.
All of the libraries offered document delivery service to their off-campus students, as well as research assistance via e-mail, phone, and sometimes chat. All students could borrow books when on site. However, only the Harvard School of Business and the Maine College of Art offered loans of physical books when students were off campus, and only books from their own library collections were available. Interlibrary loan (ILL) from other libraries was not offered.

IDSVA students had many of the services outlined above already in place, including:

- reference assistance from the IDSVA librarian via chat, e-mail, phone, as well as in person during some residencies;

- document delivery service;

- remote access to all of the library's online resources; and

- access to a university library collection, including borrowing privileges, during the summer intensive residency.

\section{Consortial partnership}

The lack of ILL access to print materials, along with the lack of a print library collection, could prove a major stumbling point for students as they progressed with their dissertations, and for IDSVA's accreditation process, as well. Since IDSVA's home office is physically located in Portland, Maine, and, in 2007, IDSVA had been accepted as $\mathrm{PhD}$ degree-granting institution in the State of Maine, the possibility for some kind of consortial arrangement with other Maine institutions seemed to hold the most promise. The University of Southern Maine was interested, but could not see a way to assist with the issue of access to physical items via ILL, for students living in other locales. We next contacted the Maine State Library in Augusta, whose mission states: "The Maine State Library facilitates access to and delivery of library services and collection resources for the State of Maine." ${ }^{4}$

The Maine State Library more than lives up to their mission. They embraced the 
idea of helping IDSVA students fully, as members of a Maine institution. They were also completely open to thinking outside the traditional ILL box, and willing to try a Netflix model, where items are mailed directly to a student's home address, and the student is then responsible for mailing the items back to the library. Essentially the Maine State Library allowed us not so much to invent, but to innovate, and do what libraries do best-deliver information and develop services tailored to their patrons needs. In addition, the consortial arrangement provides:

- additional reference assistance from the staff of Maine State Library;

- cataloging and circulating print and electronic copies of IDSVA dissertations; and

- ability to search the Maine State Libraries Marvel/One Search databases, greatly expanding students access to journal indexes and reference resources.

Full-text access to many electronic resources is limited by licensing restrictions to Maine residents only or to particular campus libraries in Maine. However, IDSVA students are able to submit online ILL requests for articles and books found in Marvel.

This one innovation to a traditional ILL service has made a born digital library a viable option for a $\mathrm{PhD}$ program. Some IDSVA students currently associated with other academic institutions have not found the need to use this service and prefer to rely on their local library.

However, the students who do not have access to another academic library, or who live in an isolated area without easy access to academic or public libraries, have been delighted with this service. Some students found that delivery of items can take a little time, but many have been very happy with how easily requests to renew have been accommodated.

One student in particular has found that access to ILL services with the Maine State Library has saved her a lot of money on book purchases and has helped her determine what books she really needed to invest in for her research.

The OCLC report "Seeking Synchronicity: Revelations and Recommendations for Virtual Reference" states that, "if we want people to accept and promote the library's role in their online information lives, we need to make the ' $\mathrm{R}$ ' [as in virtual reference] also stand for relationships." ${ }^{\text {Th }}$ The report was referring to what they deemed a warm transfer, where librarians first had in-person contact with their patrons that seemed to make virtual reference seem safer or more secure, and, in some cases, simply made the option more appealing than a Google search. But, I believe the "R" also stands for consortial relationships.

While it was vital for IDSVA to establish consortial library agreements, I think that all libraries would benefit their patrons by extending and strengthening their consortial arrangements as much as possible. IDSVA may be an island, but developing a robust consortial relationship with the Maine State Library is what is contributing to its becoming a global destination for students from a range of academic backgrounds. ${ }^{6}$

\section{Notes}

1. Barbara K. Stripling, "The Future of Libraries," American Libraries:11/12, no. 5.

2. Institute for Doctoral Studies: http:// idsva.org/ (accessed June 5, 2014).

3. G. James Daichendt, Artist Scholar: Reflections on Writing and Research (Bristol, UK: Intellect, 2012) 2.

4. Maine State Library: www.state.me.us/ msl/about/index.shtml (accessed June 5, 2014).

5. Lynne Sillipigni Connaway and Marie L. Radford, Seeking Synchronicity: Revelations and Recommendations for Virtual Reference (Dublin, Ohio: OCLC Research: 2011), www.oclc.org/content/dam/oclc /reports/synchronicity/full.pdf (accessed June 5, 2014).

6. IDSVA granted its first PhD in January 2013. 